\title{
RADA DUSZPASTERSKA: POWSTANIE, ROZWÓJ, PROBLEMATYKA
}

\author{
WSTEP
}

Rady Duszpasterskie jako instytucja są w Kościele nowością powstałą dzięki Soborowi Watykańskiemu II. Jest to instytucja będąca ciągle jeszcze w stadium doświadczeń, pełna problemów i znaków zapytania ${ }^{1}$.

Instytucja ta nie posiada w Kościele prawie żadnej tradycji. Przytaczane przez autorów teksty Ojców Kościoła ${ }^{2}$, świadczące o tym, że w niektórych wypadkach rada ludzi świeckich była brana pod uwage przy podejmowaniu przez biskupa decyzji, mówią raczej tylko o konkretnych faktach zasięgania opinii, czego przecież nigdy w Kościele nie brakowało, ale nie dotyczą rad pastoralnych jako instytucji.

Rady Duszpasterskie realizują jednak ideę tkwiącą głęboko w teologii katolickiej, której wyrazem stała się nauka Soboru Watykańskiego II o Ludzie Bożym. Nie tylko biskupi i kapłani, ale wszyscy członkowie Kościoła ponoszą odpowiedzialność za dzieło zbawcze Chrystusa ${ }^{3}$, dlatego też w Radach Duszpasterskich zyskują pewną formę udziału w zarządzie Kościołem, w takiej mierze, w jakiej pozwala na to jego hierarchiczna struktura.

1 Wprawdzie od strony prawnej Rady Duszpasterskie zostały już dość szczególowo opisane, zarówno w ustawodawstwie ogólnokościelnym, jak i partykularnym, to jednak ciągle są one $\mathrm{w}$ stadium doświadczeń $\mathrm{z}$ duszpasterskiego punktu widzenia.

2 Mowa o tekście XIV listu św. Cypriana do prezbiterów i diakonów w Kartaginie. Zob. B o ulard F., La curie et les conseils diocésains, [w:]Unam Sanctam, t. 71 La charge pastorale des éveques, Decret "Christus Dominus", Paris 1969, s. $269-270$.

3 Zob. przede wszystkim Konstytucja dogm. Lumen gentium, nn. 5, 21, 27-28, 32-33 i 37 oraz dekret Apostolicam actuositatem, nn. $2-3,10,24$. 
1. Rada Duszpasterska w pracach Soboru Watykański e g o II

Rady Duszpasterskie maja w pracach Soboru historię stosunkowo krótką.

$\mathrm{Na}$ potrzebę powołania jakiegoś diecezjalnego organu doradczego w sprawach duszpasterskich zwrócili już uwagę biskupi w swych propozycjach nadesłanych do Rzymu przed Soborem, w roku 1959, przy czym niektórzy wyraźnie domagali się, by organ ten zastąpił kapitułę katedralną w diecezji ${ }^{4}$.

Naprzeciw tym postulatom wyszła w lutym 1962 r. Komisja Przygotowawcza Soboru d/s Biskupów i Zarządu Diecezjami, w schemacie De cura animarum, proponując powołanie w diecezji organu doradczego w sprawach duszpasterskich, złożonego w zasadzie z kapłanów. Zakonnicy i katolicy świeccy, mężczyźni i kobiety, mogliby być do takiej rady powołani przez biskupa, ale celem omówienia specjalnych zagadnień '.

Również mieszana Komisja Przygotowawcza Biskupów i Zakonników, w schemacie De rationibus inter Episcopos et Religiosos, zaproponowała w 1962 r., utworzenie w diecezji rady koordynacyjnej duchowieństwa diecezjalnego i zakonnego, która mogłaby również korzystać z opinii osób zakonnych, nie będących kapłanami ${ }^{6}$.

Obydwa te rozwiązania weszły kolejno do trzeciej redakcji zarówno schematu De cura animarum, jak i do schematu De rationibus inter Episcopos et Religiosos w prawie niezmienionym brzmieniu, a następnie znalazły się, nieuporządkowane wprawdzie dobrze, ale już wspólnie w jednym schemacie, zatytułowanym De cura animarum, a oznaczonym datą 22 kwietnia $1963 \mathrm{r}^{7}$ Jest rzeczą charakterystyczną, że schemat ten dwukrotnie powołuje się na kan. 303 Kodeksu Prawa Kanonicznego, jako na pewnego rodzaju źródło i podstawę prawną proponowanej instytucji Rad Duszpasterskich ${ }^{8}$.

Jednolity, uporządkowany, zmieniony i ostateczny tekst dotyczący Rady Duszpasterskiej, znajdujemy w schemacie De pastorali Episcoporum

4 B o u lard F., dz. cyt., s. $245-246$.

5 Tamże, s. 248.

Tamże, s. 253.

Sacrosanctum Oecumenicum Concilium Vaticanum Secundum, Schema Constitutionum et Decretorum de quibus disceptabitur in Concilii sessionibus, Schemu Decreti De cura animarum, Typis Polyglottis Vaticanis 1963, s. 22, n. 42; s. 55, n. 32; s. $57, \mathrm{nn} .37-38$.

„Huiusmodi Consilium coordinans - czytamy w schemacie - aliquomodo praeformatur in CJC can. 303, quo Vacarii vel Praefecti Apostolici suadentur... 'prout siverit opportunitas, (ut) missionarios saltem praecipuos tum religiosos tum saeculares proprii territorii congregent semel saltem in anno, ut possint ex singulorum experientia et consilio deducere quae sint ordinanda perfectius": Sacr. Oec. Cone. Vat. Secundum, Schema De cura animarum, s. 28-29, nota n. 44 i s. 62 , nota n. 16. 
munere in Ecclesia $\mathrm{z}$ dnia 27 kwietnia 1964 r. ${ }^{9}$ Dokonano w nim istotnej zmiany, polegającej na dopuszczeniu do Rady Duszpasterskiej katolików świeckich, uzależniając jedynie ich udział w Radzie od woli biskupa. Redakcja tekstu, jaką znajdujemy w tym schemacie, przeszła już bez żadnych zmian do następnych projektów ${ }^{10}$ i w dniu 28 października 1965 r. stała się oficjalnym tekstem Soboru w sprawie Rad Duszpasterskich w dekrecie $O$ pasterskich zadaniach biskupów w Kościele ${ }^{11}$.

\section{Podstawy teologiczne Rady}

Podstawy teologiczne Rady Duszpasterskiej są odmienne niż Rady Kapłańskiej. Ta ostatnia opiera się o zasadę kapłaństwa posługi (sacerdotium ministeriale), podczas gdy Rada Duszpasterska ma swe uzasadnienie teologiczne $w$ kapłańst wi e w s pólnym (sacerdotium commune), wywodzącym się $\mathrm{w}$ Kościele $\mathrm{z}$ udziału w sakramentach chrztu i bierzmowania. Kapłaństwo wspólne stanowi w Radzie Duszpasterskiej podstawę wspólną i najszerszą, ale nie jedyną. Skoro bowiem Rada Duszpasterska ma się składać z duchownych i świeckich, nie sposób zredukować w niej udziału kapłanów do możliwości, jakie daje ta właśnie wspólna zasada, gdyż zachowują oni, także i jako członkowie Rady, właściwą im rolę, przysługującą im z racji przynależności do hierarchii, czyli z racji kapłaństwa posługi. Uwzględnić tu także należy szczególną rolę biskupa w diecezji, który zgodnie z wolą Soboru, stoi osobiście na czele Rady Duszpasterskiej. „Biskupi - czytamy w konstytucji dogmatycznej Lumen Gentium - kierują powierzonymi sobie poszczególnymi Kościołami jako zastępcy i legaci Chrystusa...", a władza biskupów, ,... którą w imieniu Chrystusa osobiście sprawują, jest własną, zwyczajną i bezpośrednią, choć jej wykonywanie kierowane jest w ostatecznej instancji przez najwyższą władzę Kościoła i ze względu na dobro Kościoła lub wiernych może być w pewnej mierze ograniczane" ${ }^{12}$.

- Sacrosanctum Oecumenicum Concilium Vaticanum Secundum, Schema Decreti De pastorali Episcoporum munere in Ecclesia, Typis Polyglottis Vaticanis 1964, S. 17, n. 25 .

10 Sacrosanctum Oecumenicum Concilium Vaticanum Secundum, Schema Decret De pastorali Episcoporum munere in Ecclesia, Textus emendatus et relationes, Typis Polyglottis Vaticanis 1964, s. 41, n. 41 (textus prior) i n. 27 (textus emendatus), oraz: Sacrosanctum Oecumenicum Concilium Vaticanum Secundum, Schema Decreti De pastorali Episcoporum munere in Ecclesia, Textus recognitus et modi a Commissione Conciliari De Episcopis et Dioecesium Regimine examinati, Typis Polyglottis Vaticanis 1965, s. 49 , n. 27.

11 Dekret Christus Dominus, n. 27. Należy zwrócić uwagę, że odmienne brzmienie ma tekst dotyczący Rady Duszpasterskiej zawarty w dekrecie Ad gentes. Zdaniem Carli M. podane w tym dekrecie dyspozycje mają zastosowanie jedynie do terytoriów misyjnych. Zob. Carli M., Ufficio pastorale dei vescowi e Chiese Orientali Cattoliche, Torino 1967, s. 337, nota n. 139 bis.

12 Konstytucja dogmatyczna Lumen gentium, n. 27. 
Katolicy świeccy — na wskazanej już wyżej zasadzie — mają realne uczestnictwo w misji Kościoła, jednakże przez udział w Radzie Duszpasterskiej nie zastępują ani kapłanów, ani biskupów we właściwej im roli, nie tworzą też żadnego parlamentu diecezjalnego, nie zyskują ani władzy najwyższej w diecezji, ani w ogóle jakiejkolwiek władzy, a nie mając jej, nie mogą też nikomu jej udzielać. Stanowią po prostu radę biskupa i wykonują w niej funkcje pastoralne, które są właściwie ich posłannictwu w Kościele ${ }^{13}$.

To, co zostało powiedziane, nie umniejsza w niczym roli świeckich w Kościele, ma jednak na celu jasne postawienie sprawy podstaw teologicznych Rady Duszpasterskiej, by dzięki temu uniknąć nieporozumień, których areną stał się m. in. temat Rad Duszpasterskich w Kościele, głównie $z$ powodu bezkrytycznego przeszczepiania na teren Kościoła zasad demokracji, przyjętych zwłaszcza w teorii władzy społeczności świeckich, państwowych.

To samo zagadnienie można jednak - również w świetle nauki Soboru - postawić inaczej: biskup, który mocą władzy własnej, zwyczajnej i bezpośredniej rządzi diecezją, odpowiada wprawdzie ostatecznie za Kościół lokalny w sposób specjalny, jeđnakże jego odpowiedzialności nie można traktować $\mathrm{w}$ izolacji od tej, jaką wraz $\mathrm{z}$ nim ponoszą pozostali członkowie Ludu Bożego. Sam biskup, bez duchowieństwa, i katolików świeckich Kościoła lokalnego nie tworzy i sam wyłącznie za Kościół lokalny nie odpowiada.

Taki stan sprawy domaga się, by wspólnej odpowiedzialności odpowiadało jakieś wspólne działanie. Odpowiedzialność biskupa za Kościól lokalny mierzy się nie tylko tym, czy jego zarządzenia są zgodne z jego osobistym rozeznaniem stanu i potrzeb diecezji, ale także tym, czy wykorzystał on wszystkie możliwe i dostępne środki, by ten stan i potrzeby diecezji dostrzec we właściwym świetle ${ }^{14}$.

\section{Podstawy prawne Rady}

Sobór Watykański II uznał, że jednym ze sposobów współdziałania biskupa ze wspólnotą diecezjalną będzie Rada Duszpasterska, której ogólne ramy prawne nadał dekret $O$ pasterskich zadaniach biskupów $w$ Kościele, w którym czytamy: „Jest rzeczą bardzo pożądaną, by w każdej

13 Por. Beyer J., De Consilio Pastorali adnotationes, Periodica de re morali canonica liturgica 1 (1972) 35. Również: Romita F., Pastorale e diritto canonico. Consiglio Pastorale e Consiglio Presbiterale, Monitor Ecclesiasticus 3 (1967) 505; B o u la rd F., dz. cyt., s. 261-262. ${ }^{14}$ Obszerniejsza literaturę na ten temat cytuje B e yer J., dz. cyt., S. 32-33, nota n. 7 oraz Bonicelli C. - Riboni A., Assemblea e Consiglio Pastorale Parrocchiale, Roma 1970, s. 183-192 (w tym wypacku literatura ta dotyczy problematyki Parafialnych Rad Duszpasterskich). 
diecezji ustanowiono specjalną Radę Duszpasterską, na czele której stanąłby sam biskup diecezjalny i w której miałyby udział osoby duchowne, zakonne i świeckie, specjalnie dobrane. Zadaniem tej Rady będzie badanie tego, co dotyczy dzieł apostolstwa, rozważanie tych spraw i wyciąganie praktycznych wniosków" 15.

Szczegółowe normy wykonawcze dotyczące Rady znajdujemy w Motu proprio Ecclesiae Sanctae, gdzie pap. Paweł VI ustala następujące zasady: „16. Co zaś dotyczy Rady Duszpasterskiej, bardzo zalecanej przez dekret Christus Dominus:

$\S 1$. Do Rady Duszpasterskiej należy badanie, rozważanie i podejmowanie wniosków praktycznych dotyczących spraw związanych z działalnością duszpasterską po to, by dochodziło do coraz większej zgodności życia i działania Ludu Bożego z Ewangelią.

$\S$ 2. Rada Duszpasterska, która posiada jedynie głos doradczy, może być ustanowiona w różny sposób. Zazwyczaj, chociaż z natury swej jest instytucją stałą, może być zarówno co do członków jak i co do swojej działalności powołana czasowo oraz z okazji wykonywania jakiegoś zadania. Biskup może ją zwołać, ilekroć wyda mu się to pożyteczne.

$\S$ 3. W Radzie Duszpasterskiej mają udział kapłani, zakonnicy, świeccy, specjalnie przez biskupa dobrani.

$\S$ 4. Aby cel tej Rady został rzeczywiście osiągnięty, wypada, by jej wspólną pracę poprzedzało studium, przy pomocy, jeśli zajdzie tego potrzeba, instytutów czy urzędów, które prowadzą prace w tym celu.

$\S 5$. Tam, gdzie na tym samym terytorium są hierarchowie różnego obrządku, bardzo zaleca się, aby na ile to jest możliwe, Rada Duszpasterska miała charakter międzyobrządkowy, czyli składała się z duchownych, zakonników i świeckich różnych obrządków.

$\S 6$. Inne dyspozycje są pozostawione dowolnemu uznaniu biskupa diecezjalnego, biorąc pod uwagę to, o czym mowa w n. 17.

17. § 1. Wypada, aby w sprawach dotyczących tak Rady Kapłańskiej, jak i Rady Duszpasterskiej, jak wreszcie ich relacji czy to wzajemnie do siebie, czy też w odniesieniu do innych rad biskupa istniejących na mocy obowiązującego obecnie prawa, biskupi zebrani zwłaszcza na konferencji, przedyskutowali wszystko wspólnie i wydali jednakowe normy we wszystkich diecezjach danego terytorium.

Niech biskupi zatroszczą się także o to, aby wszystkie rady diecezjalne były jak najodpowiedniej skoordynowane przez dokładne określenie ich kompetencji, wzajemne uczestnictwo członków, wspólne lub wznawiane sesje i inne sposoby.

$\S 2$. Na razie rady biskupa, istniejace na mocy obowiązującego prawa, tj. kapituły katedralne, rada konsultorów i inne podobne, jeżeli takie

15 Dekret Christus Dominus, n. 27. 
istnieją, zachowują własne zadania i własną kompetencję, dopóki nie postanowi się czegoś innego" ${ }^{16}$.

4. Ważniejsze problemy związane z powołaniem i działaniem Rad Duszpasterskich

Normy zawarte w Motu proprio Ecclesiae Sanctae, jakkolwiek ogólne, stanowiły wystarczającą podstawę do działania. Nie wszyscy biskupi jednak to działanie podjęli. Wynikało to zarówno z niezobowiązującego charakteru norm - nie zawierały one bowiem ścisłego nakazu powołania Rady Duszpasterskiej w diecezji - jak i z doświadczalnego charakteru całości przepisów zawartych w Motu proprio. Eksperymentalny charakter zawartego w tym dokumencie prawa wykorzystano w niektórych wypadkach i do tego, by nie dokonywać prób ryzykownych, a w niektórych wypadkach powołanie Rady Duszpasterskiej, zwłaszcza z udziałem świeckich, mogło takie ryzyko stanowić.

Tak czy inaczej, najpierw na Zachodzie, ale dość wcześnie także i w Polsce zaczęły się pojawiać Rady Duszpasterskie i zaczęto zyskiwać pierwsze doświadczenia. Ogólne brzmienie norm prawnych pozwalało na dość szeroką gamę rozwiązań i eksperymentów, chociaż życie poszło jeszcze dalej i eksperymenty te nie zawsze mieścily się $w$ granicach prawa ${ }^{17}$.

Powstały więc Rady Duszpasterskie nie tylko diecezjalne, jak to przewidywało Motu proprio Ecclesiae Sanctae, ale także parafialne (przykładem może być Polska, Węgry, Chile), okręgowe czy dekanalne (np. we Francji) oraz krajowe czy narodowe (np. w Holandii).

Od razu z powstaniem Rad pojawiły się ważne problemy, przed którymi stanęli najpierw biskupi i wierni, potem także i Ustawodawca.

Wśród tych problemów jednym z pierwszych była sprawa sposobu powołania $\mathrm{R}$ a dy. Robiono to różnie, począwszy od prostego dekretu Ordynariusza, poprzez konsultacje z duchowieństwem i świeckimi, aż do przejętych żywcem $z$ demokracji parlamentarnej form wyboru części lub wszystkich członków Rady. Ta różnorodność spowodowała tu i ówdzie, mniej lub więcej uzasadnione żale do biskupów, czasem doprowadziła do otwartych protestów i kontestacji.

Problem dotyczył jednak nie tylko tego, jak mianować czy wybierać, ale też i tego kogo wybierać. Chodziło o to, czy Rada ma realizować z asadę reprezentatywności, czy też nie. Jedni opowiadali się za prostą reprezentacją, inni żądali możliwie pełnej reprezentatywności, tzn. chcieli, by członkowie Rady nie tylko kogoś, jakąś grupę społeczności kościelnej po prostu reprezentowali - czy mają z nią coś wspólnego czy $308-309$.

16. 16 i 17: AAS 58 (1956) 767.

17 Zob. Wójcik W., Rada duszpasterska, Ateneum Kaplańskie 61 (1969) 
nie - ale by dla określonej grupy byli rzeczywiście reprezentatywni, stanowili niejako odbicie jej spraw i interesów.

W związku z tym powstało dalsze pytanie, czy mianowicie w Radzie Duszpasterskiej nie jest potrzebna reprezentacja proporcjonalna $i$ to nie tyle na oko, a numeryczna. W związku z tym powstały dalsze, niezliczone już kłopoty $z$ wyłonieniem tej reprezentacji, z jej użytecznością w Radzie itp.

Drugim bardzo poważnym problemem była kwestia głos u R ady. Zgodnie z zasadami teologicznymi i prawnymi, biskup może Rady słuchać, ale nie musi. W wielu wypadkach może to być dla radzących rzeczą zupełnie naturalną i zrozumiałą, staje się natomiast zagadką, powodem niezadowolenia, niesnasek i buntu, gdy życzliwą i zgodną radę wielu, wynikającą $z$ prawdziwej troski o dobro Kościoła, biskup pomija milczeniem i robi swoje.

Taka realna możliwość prowadzi do postulatów, które niekoniecznie stanowią zamach na władzę biskupa w diecezji, a mogą być wyrazem troski o dobro Kościoła, do postulatów przypisania głosowi Rady Duszpasterskiej jakiegoś waloru zobowiązującego. W krańcowych wypadkach, w Holandii, doprowadziło to - zresztą nie całkiem na tle konfliktu z biskupem - do kategorycznych żądań Rady Duszpasterskiej już nie tylko w sprawach diecezjalnych, ale ogólnokościelnych.

W wielu wypadkach starano się ten problem przemyśleć i postawiono go nieco inaczej niż Motu proprio Ecclesiae Sanctae, które daje biskupowi pełną swobodę działania. Uważano, że nie jest sprzeczne z rolą biskupa $\mathrm{w}$ diecezji, jeśli będzie on nie tylko mógł, ale nawet jeśli będzie musiał zwołać Radę w określonym terminie, wysłuchać jej w określonych sprawach, czy wreszcie iść za jej zaleceniami w niektórych wypadkach, albo uzasadnić swoje odmienne postępowanie.

$\mathrm{Z}$ biegiem czasu pojawił się w związku z Radami Duszpasterskimi dalszy problem. Wielu biskupów bowiem w ogóle takiej rady nie powołało. Sprzeciwy w stosunku do takiego stanowiska pojawiły się zarówno ze strony duchowieństwa, jak i ze strony świeckich. Pomijam tu diecezje, w których nie było warunków do powołania Rady, albo te, w których byłaby ona niepotrzebna, zwracam jedynie uwage na problem, jaki z tego powodu powstał w diecezjach, którym Rada taka jest potrzebna.

Osobną wielką kwestią, która na nowo ujawniła się w związku z Radami Duszpasterskimi, jest udział katolikó w świeckich w życiu Kościoła. Sprawa jest znana chociażby z naszego polskiego terenu.

Jeszcze innym poważnym zagadnieniem okazało się właściwe ułożenie stosunku Rady Duszpasterskiej do Rady Kapłańskiej, kapituły katedralnej, kurii i jej różnych wydziałów. 
Wszystkie te problemy, których zarys przedstawiłem, a które na tle warunków lokalnych wyglądają nieraz dramatycznie, spowodowały zainteresowanie się Radami przez Stolicę Apostolską.

Już w październiku 1969 r. Kongregacja d/s Duchowieństwa postawiła swym członkom kardynałom pytanie, czy jest rzeczą pożyteczną bliżej określić naturę i działalność Rady Duszpasterskiej, w stosunku do powiązań, jakie winna ona mieć z Radą Kapłańską, a jeśli tak, to w jaki sposób należy to zrobić.

Odpowiedź była właściwie negatywna, bo dilata, a to z powodu braku wystarczających i ścisłych danych o Radach Duszpasterskich w świecie.

Postanowiono zatem zwrócić się do wszystkich Konferencji Biskupich, by wypowiedziały się na ten temat. W tym celu sporządzono wstępny schemat dokumentu - podobnego nieco do Listu Okólnego Kongregacji d/s Duchowieństwa w sprawie Rad Kapłańskich - i przesłano go Konferencjom 12 marca 1971 r., by na jego tle uzyskać potrzebne informacje ${ }^{18}$.

Dokument zatytułowany De Consilio Pastorali ${ }^{19}$, po wstępie, w którym wspomniano normy Soboru i Motu proprio Ecclesiae Sanctae o Radach Duszpasterskich, zawierał sześć rozdziałów: 1) Określenie i cel Rady Duszpasterskiej, 2) Natura prawna tej instytucji, 3) Skład Rady Duszpasterskiej, 4) Przewodnictwo Rady i jej zebrania, 5) Stosunek Rady Duszpasterskiej do Rady Kapłańskiej, 6) Stosunek Rady Duszpasterskiej do innych tego rodzaju instytucji.

Dokument ten, pomyślany zapewne jako projekt nowego ustawodawstwa w dziedzinie Rad Duszpasterskich, w zasadzie nie zawierał nic nowego, poza szerszym rozprowadzeniem i uzasadnieniem myśli Soboru i Motu proprio Ecclesiae Sanctae i drobnymi już na tym tle ustaleniami dotyczącymi rozgraniczenia kompetencji Rady Duszpasterskiej i Kapłańskiej. Nie nakazywał też, a jedynie zalecał powołanie Rady w diecezji.

Projekt spotkał się z bardzo ostrą krytyką większości Konferencji Biskupich, które nadesłały swe uwagi. Głosy - jak zawsze w tego rodzaju dyskusji — były bardzo różne. W nielicznych wypadkach wyrażono zgodę na projekt i chwalono go (np. Portugalia, Argentyna, Costa Rica, Porto Rico), inni wyrażali umiarkowaną krytykę (np. Kanada, Francja, Włochy), inni wreszcie całkowicie dokument odrzucali, uważając, że nie może on stanowić podstawy dyskusji na ten temat (np. Holandia).

18 Sacra Congregatio pro Clericis, Litterae Circulares ad Patriarchas, Primates, Archiepiscopos, Episcopos aliosque locorum Ordinarios de Consiliis Pastoralibus iuxta placita Congregationis Plenariae Mixtae die 15 Martii 1972 habitae. N. 140686/I, Romae die 25 Ianuarii 1973. List ten nie został opublikowany w Acta Apostolicae Sedis. Tekst Polski zob. Ateneum Kapłańskie 81 (1973) 125-132.

19 Sacra Congregatio pro Clericis, Prot. N. 135077/I, Romana et Aliarum, De Consiliis Pastoralibus, Status quaestionis. 
Projektowi zarzucano jurydyzm, jednostronne spojrzenie na zagadnienie Rady, broniące tylko biskupa i jego pozycji w Kościele lokalnym, a nie uwzględniające w wystarczający sposób roli pozostałych członków Ludu Bożego.

Wynikiem tej krytyki było postanowienie zwołania wspólnego zebrania kilku zainteresowanych sprawą dykasteriów Kurii rzymskiej, a mianowicie Kongregacji d/s Biskupów, Kongregacji d/s Duchowieństwa, Kongregacji d/s Zakonów i Instytutów Świeckich oraz Rady Swieckich. To wspólne zebranie (congregatio ordinaria mixta) zostało zwołane na dzień 15 marca 1972 r. i miało dać odpowiedź na następujące pytania:

1) Mając na uwadze naturę i znaczenie Rady Duszpasterskiej, na ile trzeba by się domagać jej powołania w diecezji? 2) Jakie są zadania Rady Duszpasterskiej, jaki jej skład i czas trwania? 3) Jak należy organizować Radę Duszpasterską, czy tylko na szczeblu diecezjalnym (dekanalnym i parafialnym), czy także na szczeblu międzydiecezjalnym (narodowym czy międzynarodowym)?

5. Rady Duszpasterskie w świetle obowiązującego prawa kościelnego

Odpowiedź na postawione wyżej pytania znajdujemy w Liście Okólnym Kongregacji d/s Duchowieństwa z dnia 25 stycznia $1973 \mathrm{r} .{ }^{20}$, a także w wydanej niespełna miesiąc później, bo dnia 22 lutego $1973 \mathrm{r}$. przez Kongregację $\mathrm{d} / \mathrm{s}$ Biskupów Instrukcji o pasterskiej postudze biskupów, zaczynającej się od słów: Ecclesia imago 21.

Zwłaszcza List Okólny Kongregacji d/s Duchowieństwa traktuje szerzej o problematyce Rad Duszpasterskich, kreśląc obszernie założenia teologiczne tego organu ${ }^{22}$ i wskazując na drogę, na której doszło do ponownego zajęcia się nim przez Stolicę Apostolską ${ }^{23}$.

Oto w krótkim zarysie treść tych wypowiedzi.

a) Powołanie Rady

Powołanie Rady w diecezji pozostawiono nadal decyzji biskupa, wskazano jednak na użyteczność tej instytucji i w związku z tym bardzo zalecano jej utworzenie ${ }^{24}$.

b) Zadania

20 S. Congr. pro Clericis, Litterae Circulares. Zob. nota n. 18. W dalszym ciągu będę cytowal ten list $\mathrm{w}$ formie skrótu LO (List Okólny) z podaniem wewnętrznej numeracji tekstu.

21 S. Congregatio pro Episcopis, Directorium de pastorali ministerio Episcoporum, Typis Polyglottis Vaticanis 1973, nn. 147, 168 i 179.

22. LO, Proemium.

23 LO, n. 5.

24 LO, n. 6. 
Zadania Rady zostały nakreślone bardzo szeroko, Kongregacja wskazała jednakże wyraźnie, jakich granic nie należy przekraczać.

I tak, obok zadań postawionych przed Radami Duszpasterskimi w dekrecie soborowym Christus Dominus (n. 27) i w normach wykonawczych do tego dekretu, zawartych w Motu proprio pap. Pawła VI Ecclesicae Sanctae, List Okólny mówi, że studium Rady mogą być powierzone ,te kwestie, które zostały wskazane bądź przez biskupa diecezjalnego, bądż zostały zaproponowane przez członków Rady i przez biskupa zatwierdzone, a odnoszą się do duszpasterstwa wykonywanego w obrębie diecezji" 25 .

Obok tej ogólnej zasady List Okólny wymienia też przykładowo szereg spraw, w których Rada Duszpasterska może przyjść biskupowi z bar-dzo pożyteczną pomocą. Chodzi mianowicie o przedstawianie biskupowi propozycji i sugestii w sprawach różnych poczynań misyjnych, katechetycznych i apostolskich $\mathrm{w}$ diecezji, odnoszących się do podniesienia wiedzy religijnej i poziomu życia sakramentalnego wiernych, pomocy w pracy apostolskiej kapłanów, w stosunku do różnych środowisk społecznych czy terenów diecezji, w oddziaływaniu na opinię publiczną w różnych sprawach dotyczących Kościoła. Rada może też być pożyteczna przy rozeznaniu środowiska i jego potrzeb, potrafi czasem wskazać biskupowi właściwe sposoby zaradzenia potrzebom duchowym tego środowiska.

Wymieniając te różnorakie możliwości działania Rady Duszpasterskiej, List Okólny - niewątpliwie w oparciu o smutne doświadczenia niektórych Rad - jasno stawia sprawę, czym nie może się ona zajmować. Do spraw tych należą kwestie zasad wiary, moralności chrześcijańskiej oraz powszechnego prawa kościelnego, a także te zagadnienia duszpaster.skie, z którymi związane jest wykonywanie jurysdykcji kościelnej czy też władzy administracyjnej.

Wyłączenie tych spraw spod kompetencji Rad Duszpasterskich jest umotywowane $z$ jednej strony rolą biskupa $\mathrm{w}$ diecezji, który w łączności z papieżem jest na własnym terenie z prawa Bożego, jedynym oficjalnym nauczycielem wiary, z drugiej zaś strony istnieniem Rady Kapłańskiej, która - zgodnie z postanowieniami Soboru Watykańskiego II i kościelnego prawodawstwa posoborowego, jako senat biskupa, wspomaga go w zarządzie diecezją ${ }^{26}$.

Wykluczenie spod kompetencji Rady Duszpasterskiej spraw wymagających posiadania jurysdykcji kościelnej nie jest jednak bezwzględne. Rada może zabrać w tych kwestiach głos, byleby tylko rzeczywiste wykonanie związanej z nimi władzy należało do biskupa, po wysłuchaniu w określonych wypadkach, zdania Rady Kapłańskiej.

25 LO, n. 9.

26 Motu proprio pap. Pawka VI Ecclesiae Sanctae, I, n. 15, § 1: AAS 58 (1966) 766. 
List Okólny wyraźnie także zaznacza, że dialog między hierarchią a katolikami świeckimi, którego instytucjonalnym wyrazem są Rady Duszpasterskie ${ }^{27}$, jest tylko jednym ze sposobów nawiązania i utrzymania kontaktów między duchownymi a wiernymi i w niczym nie prze-kreśla prawa, jakie przysługuje każdemu z członków Kościoła, by osobiście wypowiadał się i wyrażał własne życzenia w sprawach dotyczących społeczności religijnej, w której żyje.

c) Skład osobowy

Chociaż członkowie Rady nie mogą być uważani za reprezentantów wspólnoty diecezjalnej $\mathrm{w}$ sensie prawnym, to wypada jednak - stwierdza List Okólny - by stanowili oni, wedle możliwości, obraz tej wspólnoty. W Radzie winni brać udział kapłani, osoby zakonne i świeccy, tak dobrani, by rzeczywiście reprezentowali cały Lud Boży diecezji, różne jej regiony, grupy społeczne i zawodowe, różny stopień zaangażowania wiernych $\mathrm{w}$ indywidualnych i zbiorowych poczynaniach apostolskich.

$\mathrm{Na}$ baczną uwagę zasługuje podkreślenie, by większość członków Rady stanowili świeccy, oni bowiem tworzą przeważającą część wspólnoty diecezjalnej. Podkreślenie to i jego motywacja wskazują, że do Rady Duszpasterskiej zastosowano, przynajmniej częściowo zasadę reprezentacji proporcjonalnej. Dowodzi to też, że Kościół darzy świeckich katolików coraz szerszym kredytem zaufania ${ }^{28}$, przezwyciężając powoli, mocno jeszcze zakorzenione przekonanie o ich biernej postawie w życiu społeczności kościelnej. Przekonaniu temu dawano wyraz między innymi w ramach Rad Duszpasterskich, tworząc je, mimo wyraźnych przepisów prawa kościelnego, wyłącznie $\mathrm{z}$ osób duchownych ${ }^{29}$.

Potwierdzając zalecenia znajdujące się w Motu proprio pap. Pawła VI Sacrum diaconatus ordinem, z 18 czerwca 1967 r. ${ }^{30}$, List Okólny wspomina, że w Radzie Duszpasterskiej winni uczestniczyć także stali diakoni, o ile ta instytucja została na jakimś terenie wprowadzona ${ }^{31}$.

W stosunku do osób zakonnych określono wyraźnie, że ich wejście do Rady wymaga zgody właściwych przełożonych ${ }^{32}$.

d) Ilość członków

Rada Duszpasterska winna być organem czynnym i skutecznym, co narzuca pewne rygory w stosunku do ilości członków. Trudno w skali ogólnokościelnej wskazać tutaj jakąś idealną cyfrę, dlatego też przyjęto

27 Zob. Pieronek T., Aspekty prawne dialogu między hierarchia a katolikami świeckimi, Prawo Kanoniczne 1-2 (1970) 211-214.

${ }_{28}$ Zob. We ron E., Dokument o Radach Duszpasterskich, Collectanea Theologica 3 (1974) $136-137$.

29 Zob. W ójcik W., dz. cyt., s. 302, oraz nota n. 9.

30 AAS 59 (1967) 702.

31 LO, n. 7.

32 ,Ad Religiosos et Religiosas vero quod attinet, ab Episcopo nominentur cum licentia competentis Superioris vel Antistitae" LO, n. 7. 
ogólniejszą, negatywną zasadę, że liczba osób biorących w niej udział nie powinna być zbyt wielka, by nie utrudniać sprawności jej działania ${ }^{33}$.

e) Kadencja Rady, rotacja członków

W odniesieniu do kadencji Rady potwierdzono normę zawartą w Motu proprio Ecclesiae Sanctae ${ }^{34}$, że w czasie wakansu stolicy biskupiej Rada przestaje istnieć (cessat). Nic nie stoi wszakże na przeszkodzie, by Ordynariusz rządzący diecezją sede vocante, zwoływał członków Rady celem zasięgnięcia ich zdania ${ }^{35}$.

Mandat członków Rady może trwać różnie. List Okólny sugeruje jednak, by ci spośród członków, którzy wchodzą do Rady z racji piastowania jakiegoś urzędu w diecezji, byli w niej tak długo, jak długo pozostają na urzędzie. W odniesieniu do pozostałych osób wskazane jest zastosowanie rotacji, tak jednak, by zmiany miały charakter raczej ewolucyjny. Zmiana wszystkich członków naraz jest niepożądana, nie pozwala bowiem na ubogacenie nowej Rady doświadczeniami ustępującej.

Biskup może tak rozstrzygnąć sprawę kadencji członków Rady, jak wymagają tego miejscowe warunki, ale powinien to zrobić na piśmie, w zatwierdzonych przez siebie statutach Rady ${ }^{36}$.

f) Głos doradczy

Wbrew niektórym sugestiom, wysuwanym zwłaszcza w początkowej fazie powstawania Rad Duszpasterskich ${ }^{37}$, Stolica Apostolska potwierdziła jeszcze raz doradczy charakter Rady, niemniej uczyniła pewne ustępstwo na rzecz tych, którzy domagali się mocniejszego zaakcentowania wagi opinii wyrażanych przez nią.

Decyzje we wszystkich problemach przedkładanych przez Radę pozostawiono biskupowi. Nie mogło być inaczej. Zwrócono jednakże uwagę, że głos wiernych, żyjących we wspólnocie diecezjalnej i wyrażany w duchu prawdziwej jedności, jest bardzo użyteczny przy formowaniu właściwej decyzji. Biskup zatem powinien ten głos wysoko cenić, szczególnie w tych wypadkach, kiedy jest on jednomyślny ${ }^{38}$.

g) Rodzaje Rad Duszpasterskich

W odpowiedzi na pytanie, jakie rodzaje Rad Duszpasterskich należy w Kościele organizować, udzielono bardzo interesującej odpowiedzi. „Nie ma przeszkód - stwierdza List Okólny - aby na terenie diecezji tworzono Rady o identycznym charakterze i funkcji, czy to prafialne, czy to tzw. okręgowe (dla różnych dekanatów albo grup społecznych itp.) ${ }^{39}$.

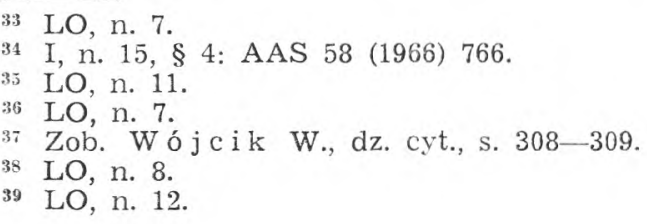


Uznano natomiast za niewskazane, przynajmniej obecnie, powoływanie podobnych organów na szczeblu międzydiecezjalnym, prowincjalnym, regionalnym, narodowym czy międzynarodowym, co jednakowoż nie wyklucza możliwości ustanawiania o takim właśnie zasięgu organów specjalistycznych o charakterze technicznym lub wykonawczym, które wspomagałyby Konferencje Biskupie ${ }^{40}$.

W sumie, biorąc pod uwagę całość Listu Okólnego Kongregacji d/s Duchowieństwa, do której kompetencji należy wszystko, co wiąże się z Radami Duszpasterskimi ${ }^{41}$, należy stwierdzić, że stanowi on nowy, poważny krok na drodze do określenia i utrwalenia trudnej do ścisłego opisu prawnego, a bardzo potrzebnej instytucji, służącej uaktywnieniu życia religijnego. Kongregacja $\mathrm{d} / \mathrm{s}$ Duchowieństwa uczyniła wiele, by zachowując wskazane przez Sobór Watykański II istotne elementy tej instytucji, uwzględnić te wszystkie postulaty Konferencji Biskupich, które w oparciu o zdobyte doświadczenie pozwoliłyby na uczynienie z Rady skuteczniejszego organu duszpasterstwa.

6. Parafialne Rady Duszpasterskie

Sobór Watykański II i szereg dokumentów kościelnych po nim wydanych, przez kilka lat rozważały wyłącznie problematykę Rad Duszpasterskich skupionych wokół biskupa. Nie stanęło to na przeszkodzie temu, że zarówno Diecezjalne, jak i upodabniające się do nich Parafialne Rady Duszpasterskie pojawiły się w Kościele niemal równocześnie.

Oficjalnie, na temat Parafialnych Rad Duszpasterskich wypowiedział się jednak dopiero List Okólny Kongregacji d/s Duchowieństwa z 1973 r., przytoczony wyżej.

Na tej podstawie można - mutatis mutandis - zastosować do Parafialnej Rady Duszpasterskiej wszystkie przepisy, które dotyczą Rad Diecezjalnych i rozważać na poziomie życia wspólnoty parafialnej te wszystkie problemy, przed którymi staje także Rada w diecezji.

Zasadnicza różnica między tymi dwoma rodzajami Rad polega na tym, że na czele Rady Diecezjalnej stoi jedyny ustawodawca diecezjalny, jakim jest biskup ordynariusz, podczas gdy Radzie Parafialnej przewodzi proboszcz, wykonujący duszpasterstwo w zastępstwie biskupa i nie posiadający żadnych uprawnień ustawodawczych.

Dla uniknięcia nieporozumień należy jasno stwierdzić, że Parafialna Rada Duszpasterska, o której tu mowa, nie wiele ma wspólnego z istnie-

40 „Patres existimaverunt non esse opportunum, saltem pro praesenti tempore, ut Consilia pastoralia aliave similia organa instituerentur in ambitu interdioecessano, provinciali, regionali, nationali vel internationali, non tamen excludentes constitutionem organorum specialium technicae naturae vel exsecutivae, quorum erit, opera adhibita christifidelium selectorum, auxilium ferre Episcopis in Conferentiis coadunatis": LO, n. 12.

41 Konstytucja Apostolska Regimini, n. 69, § 1: AAS 59 (1967) 909. 
jącymi gdzieniegdzie w Polsce Radami Parafialnymi znanymi czasem pod nazwą Komitetów Parafialnych, dla których Konferencja Episkopatu Polski zaproponowała w 1947 r. jednolity, ogólnopolski statut. Komitety te posiadały ,prawo do zwyczajnego zarządu majątkiem kościelnym, w myśl przepisów prawa kanonicznego oraz zarządzeń ordynariusza' (art. 9a) ${ }^{42}$.

Parafialne Rady, których powołanie postuluje się dzisiaj, mają być, jak wskazuje nazwa „duszpasterskimi”, co oznacza, że będą one uczestniczyć, we właściwy im sposób, w pasterskiej i apostolskiej misji Kościoła. I pod tym względem różnią się one zasadniczo od dawnych, gdyż spod uprawnień poprzednich Rad były wprost wyjęte ,,wszelkie sprawy należące do urzędu duszpasterskiego" (art. 12 wspomnianego Statutu).

7. Stanowisko Konferencji Episkopatu Polski w sprawie Rad Duszpasterskich

O ile wiadomo ze źródeł opublikowanych, Konferencja Episkopatu Polski nie wypowiedziała się szerzej w żadnym dokumencie o Diecezjalnych Radach Duszpasterskich, nie ogłosiła w tej sprawie żadnych jedno-litych przepisów, o których mowa w Motu proprio pap. Pawła VI Ecclesiae Sanctae ${ }^{43}$.

Jedynie Komisja Apostolstwa Świeckich przy Konferencji Episkopatu Polski w wydanym przez siebie w dniu 2 czerwca 1969 r. w Krakowie Dyrektorium Apostolstwa Swieckich, w n. 85 zaleca: „Na szczeblu diecezjalnym powinny powstać Diecezjalne Rady Duszpasterskie... z udziałem ludzi świeckich. Członków Rady Diecezjalnej powołuje Ordynariusz, który określa i zatwierdza dyrektywy dotyczące działalności i kompetencji Rady Diecezjalnej. Zaleca się wyodrębnić w Radzie Diecezjalnej osobną sekcję dla spraw apostolstwa świeckich" 44.

To samo Dyrektorium zajmuje się szerzej Radami Parafialnymi stwierdzając, że ,stosownie do zalecenia soborowego powinna w każdej parafii powstać Rada Parafialna" (DAŚ, n. 80). Do takiej Rady należy powoływać obok księży i osób zakonnych zaangażowanych w apostolstwo Kościoła, także gorliwych i wybitnych parafian świeckich, którym tego

42 Statut Rad Parafialnych, opublikowany w: Notificationes e Curia Metropolitana Cracoviensi 5-6 (1958) 247. Na temat Duszpasterskich Rad Parafialnych zob. ponadto: Sobański R., Uwagi o strukturze Parafialnej Rady Duszpasterskiej, Ateneum Kaplańskie 81 (1973) 133-134; P i r on ek T., Podstawy prawne Parafialnych Rad Duszpasterskich, Notificationes e Curia Metropolitana Cracoviensi 5-6 (1974) 88-93; K a m ińsk i R., Parafialna Rada Duszpasterska, Wiadomości Diecezjalne Podlaskie 8 (1976) 240-254; S z t a f r o w s k i E., Współpracownicy biskupa diecezjalnego $w$ pasterskim postugiwaniu, Warszawa 1977, s. 258-260.

43 I, n. 17. § 1: AAS 58 (1966) 767.

44 Tekst Dyrektorium Apostolstwa Swieckich (cytuję: DAŚ) nie został nigdzie w całości opublikowany. 
rodzaju zajęcie nie będzie przeszkadzało w pracy zawodowej (DAŚ, n. 81). Pomyślano również o Radach Międzyparafialnych w większych miastach. Rady tego rodzaju, zdaniem Komisji, może zwoływać Ordynariusz ná wniosek zainteresowanych proboszczów (DAŚ, n. 83), określono w głównych zarysach zadania obydwu rodzajów Rad (DAŚ, nn. 82-83). Równocześnie jednak Komisja stanęła na stanowisku, że: „Działalność Rad Parafialnych i Międzyparafialnych regulują odnośne dyrektywy, które dla całej Polski wyda Konferencja Episkopatu Polski, a dla poszczególnych diecezji miejscowy Ordynariusz. Do czasu wydania odgórnych zarządzeń, poleca się gorliwości i roztropności księży proboszczów podejmowanie w tej dziedzinie inicjatyw i doświadczeń na własną rękę. Udane eksperymenty pozwolą na sformułowanie bardziej życiowych dyrektyw ogólnych" (DAŚ, n. 84).

Prace nad wydaniem ogólnopolskich zaleceń w sprawie Parafialnych Rad Duszpasterskich trwały kilka lat i były prowadzone przez Komisję Apostolstwa świeckich przy Episkopacie Polski. Dokument w tej sprawie został przyjęty przez 150-te posiedzenie Konferencji Episkopatu Polski w Warszawie, dnia 18 listopada 1975 r. Wytyczne $w$ sprawie Parafialnych Rad Duszpasterskich ${ }^{45}$, taki bowiem tytuł nosi ten dokument, zostały podzielone na trzy części: I. Wprowadzenie, II. Dyrektywy praktyczne i III. Zakończenie.

Nie sposób poddawać tutaj ten dokument szczegółowej analizie, bez narażania się na częste powtarzanie tego, co już zostało powiedziane. Wytyczne są napisane jasno i nie wymagają komentarza. Z natury rzeczy sięgają do szczegółów, których dokumenty ogólnokościelne nie omawiają. Taka zresztą była myśl Ustawodawcy kościelnego, kiedy zlecał Konferencjom Biskupim bliższe zajęcie się problemem Rad na własnym terenie.

\section{ZAKOŃCZENIE}

Na przestrzeni dziesięciu lat po Soborze Watykańskim II, który wprowadził Rady Duszpasterskie jako nową instytucję dla ożywienia diecezjalnych i parafialnych wspólnot religijnych, można stwierdzić rzeczywisty postęp, tak w ustawodawstwie kościelnym powszechnym i partykularnym, jak i w praktycznym zastosowaniu tego ustawodawstwa w różnych rejonach świata.

Rady Duszpasterskie mają przed sobą wielkie perspektywy rozwoju. Jest to jednak instytucja w realizacji bardzo trudna, wymagająca pogłębionej świadomości religijnej wszystkich, którzy pracę w Radzie traktują na serio.

45 Tekst został opublikowany w: Notificationes e Curia Metropolitana Cracoviensi 1 -2 (1976) $20-26$. 
Dobrze się stało, że i katolicy w Polsce otrzymali do rąk wskazówki, czym są i jak powinny działać na naszym terenie Duszpasterskie Rady Parafialne. Wytyczne Episkopatu w tej sprawie dają wiele materiału do przemyśleń i sporo wskazań praktycznych.

\section{IL CONSILIO PASTORALE: ORIGINE - SVILUPPO - PROBLEMATICA}

\section{SOM M A R I O}

L'idea del Consilio Pastorale è stata elaborata durante il Concilio Vaticano II ed ha trovato l'espressione già nei progetti dei documenti finali, cioè negli schemi: De cura animarum (1962 a.), De rationibus inter Episcopos et Religiosos (1963 a.), De pastorali Episcoporum munere in Ecclesia (1964 a.). Quest'ultimo progetto approvato dal Concilio ha sancito nella Chiesa universale il Consilio Pastorale come nuovo organo consultivo del vescowo diocesano.

Consili Pastorali trovano suo fondamento teologico nel sacerdozio comune che nasce dal sacramento del Battesimo e della Cresima. Questo fondamento teologico però non è unico perchè fra i membri del Consilio Pastorale troviamo non soltanto i laici ma anche i sacerdoti i quali conservano, essendo nel Consilio, suoi diritti e funzioni del sacerdozio ministeriale.

Laici, avendo realmente parte nella missione della Chiesa, per il lavoro nel Consilio Pastorale non sostituiscono ne i sacerdoti ne il vescovo, non costituiscono nessun parlamento diocesano, non acquistano nessuna giurisdizione, hanno però il diritto di suggerire al vescovo iniziative pastorali. Il vescovo da parte sua può governare la diocesi da solo, ma nella luce dei principi del Concilio farà meglio ascoltando il Consilio Pastorale. Buon vescovo rendendosi conto che i laici hanno sua responsabilità nella vita della Chiesa sempre cercherà di ascoltargli. Per il vescovo che non è il buon pastorale delle anime nessun Consilio sarà utile.

Fondamenti giuridici del Consilio Pastorale si trovano nel decreto conciliare De Episcoporum munere in Ecclesia e norme di esecuzione soprattutto nel Motu proprio di papa Paolo VI Ecclesiae Sanctae (n. 16).

Norme giuridiche riguardanti i Consili Pastorali sono così generali che consentono al vescovo grande libertà dalla quale sorgono molti problemi di natura giuridica e nella vita cotidiane dei Consili Pastorali.

La prima cosa da stabilire è il modo di scegliere i membri del Consilio. Essi posśono essere nominati o eletti ma sepre resterà il problema della adeguata rappresentatività dei membri del Consilio. Altri problemi sorgono circa il valore del voto espresso dalla assemblea del Consilio, circa la necessità di erigerlo nella diocesi, circa i rapporti del Consilio con diversi organi di consultazione nella diocesi e così via.

Principali problemi del Consilio Pastorale sono stati sottoposti alla S. Congregazione del Clero che ha emanato il 25 gennaio 1973 r. la Lettera Circolare nella quale ha esposto la presa di posizione della Santa sede verso vari problemi legati con il Consilio Pastorale.

Alla luce di questa Lettera Circolare e della Istruzione della S. Congregazione per i Vescovi, intitolata Ecclesiae imago del 1973 a. l'autore descrive Consilio Pastorale dal punto di vista giuridico e alla fine indica la presa di posizione della Conferenca Episcopale Polacca sui Consili Pastorali, specialmente quelli Parocchiali. 